\title{
Youth Center Dengan Pendekatan Arsitektur Regionalisme Di KABUPATEN MAGELANG
}

\author{
Risya Agus Arifah, Edi Pramono Singgih, Marsudi \\ Program Studi Arsitektur \\ Jurusan Arsitektur Fakultas Teknik \\ Universitas Sebelas Maret Surakarta \\ Email : risyaa13@gmail.com
}

\begin{abstract}
Designing Youth Center in Magelang Regency, motivated by positive environmental needs of adolescents, especially in Magelang Regency which currently didn't have a special space to carry out various activities such as sports, arts and skills, as well as the potential and achievements of young people in Magelang Regency in the field of sport and art have not received guidance. The purpose of this architectural planing is to provide a place for the youth in Magelang Regency wich can accomodate recreation, socializing, innovate, and develop talent, so that they can have wholesome recreational facility that can develop their interests and talents as well as socializing ability wich will bring the better changes. The approach used in determining the design is by using the concept of Regionalism Architecture which is applied in form and fasade building as well as the pattern of mass arrangement. The result obtained is the design of a training and recreation facilities for young people that is Youth Center in Magelang Regency with Regionalism Architecture approach, wich can visible in the use of Borobudur Temple elements, such as stone material, stone step pyramid structure landscape arragement, centrally balanced composition, application of Borobudur Temple ornamens, The main building floor plan wich has a form that resembles Borobudur Temple floor plan, as well as the shape of a pyramid roof wich is the application form from Borobudur Temple stupa.
\end{abstract}

Keywords:

Adolescent, Borobudur Temple, Fasade Building. Regionalism Architecture, Youth Center, Youth Facility.

\section{PENDAHULUAN}

Masa remaja merupakan masa yang penting dalam perkembangan manusia. Pada masa tersebut manusia mulai mencari identitas dalam rangka mempersiapkan diri menghadapi masa dewasa. Pada masa tersebut remaja cenderung ingin menyalurkan semua keinginannya. Hal tersebut juga didukung oleh pengaruh lingkungan tempat tinggalnya. Penyaluran keinginan yang didukung oleh pengaruh lingkungan positif akan membentuk pribadi remaja yang positif, sebaliknya dukungan lingkungan negatif, akan membawa pengaruh negatif pula.

Remaja adalah potensi manusia yang peru dimanfaatkan, sehingga dibutuhkan pembinaan bagi remaja tersebut agar menghasilkan kader penerus bangsa yang dapat membawa perubahan ke arah yang lebih baik (Mappiare, 1982).

Sayangnya, potensi remaja khususnya di Indonesia saat ini belum mendapatkan perhatian khusus. Terbukti dengan penyaluran kegiatan remaja yang tidak diikuti dengan perkembangan fasilitas positif yang mewadahinya.

Kabupaten Magelang merupakan salah satu kabupaten di Indonesia yang belum mempunyai fasilitas khusus bagi remaja untuk melakukan kegiatan. Menurut Dinas Pendidikan, Pemuda dan Olahraga Kabupaten Magelang jumlah remaja pada tahun 2010 tercatat sekitar 82.498 jiwa, dan bertambah menjadi 117.610 jiwa pada tahun 2013, terhitung dari jumlah remaja yang bersekolah.

Dengan banyaknya jumlah remaja di Kabupaten Magelang tersebut, maka 
potensi pembinaan dan pengembangan bakat bagi remaja dirasa cukup tinggi, ditambah dengan prestasi-prestasi yang telah diraih oleh remaja di Kabupaten Magelang.

Berdasarkan tinjauan di atas, adanya sebuah fasilitas yang dapat mewadahi kegiatan remaja di Kabupaten Magelang tentunya akan sangat membantu untuk menciptakan generasi-generasi yang dapat membawa perubahan ke arah yang lebih baik. Oleh karena itu dibutuhkan suatu wadah yang dapat menampung kegiatan remaja, baik kegiatan pengembangan bakat, rekreasi, dan juga sosialisasi berupa sebuah youth center.

Bangunan youth center di Kabupaten Magelang yang dirancang, menggunakan konsep Arsitektur Regionalisme. Regionalisme diharapkan dapat menghasilkan bangunan yang bersifat abadi, melebur atau menyatu antara yang lama dan yang baru, antara regional dan universal (Curtis, 1985). Penerapan konsep Arsitektur Regionalisme pada youth center di Kabupaten Magelang mengambil unsurunsur yang ada pada Candi Borobudur, yang merupakan salah satu ikon yang terdapat di Kabupaten Magelang, yang diharapkan dapat memunculkan citra budaya lokal.

\section{METODE}

Metode yang digunakan untuk mencapai tujuan dan sasaran perencanaan dan perancangan adalah metode pemrograman arsitektur yang terdiri dari gagasan awal, temuan dan penelusuran masalah, pencarian data, pengolahan data dan informasi, konsep perencanaan (building performance concept), konsep perancangan (programming and design) dan transformasi arsitektur.

Penelusuran masalah di mulai dengan melakukan survey ke Dinas Pendidikan, Pemuda dan Olahraga Kabupaten Magelang. Permasalahan yang didapat yaitu kurangnya sarana dan prasarana yang menunjang kegiatan remaja.
Permasalahan yang ditemukan kemudian dianalisis (building concept), yaitu mengidentifikasi masalah yang ada berdasarkan konsep desain fasilitas remaja yang diselesaikan dengan penerapan Arsitektur Regionalisme. Arsitektur Regionalisme dipilih sebagai tema pendekatan dikarenakan keterkaitan dengan program pelestarian kebudayaan bagi generasi muda di Kabupaten Magelang, sehingga nantinya diharapkan bangunan yang direncanakan akan lebih menonjolkan sisi budaya Kabupaten Magelang.

Arsitektur Regionalisme yang diterapkan pada bangunan yang direncanakan yaitu mengambil elemenelemen yang terdapat pada Candi Borobudur, yang saat ini merupakan salah satu ikon bagi Kabupaten Magelang, sehingga diharapkan bangunan yang direncanakan dapat memunculkan citra Kabupaten Magelang.

Arsitektur Regionalisme sebagai tema pendekatan dalam perencanaan Youth Center di Kabupaten Magelang juga sebagai batasan dalam menentukan bentuk, pola tata massa, tampilan bangunan, serta material bangunan.

Analisis perancangan (building criteria) dilakukan dengan mengolah data yang telah terkumpul dan dikelompokkan berdasarkan pemrograman fungsional, performansi dan arsitektural.

a. Pemrograman fungsional untuk mengidentifikasi pengguna Youth Center di Kabupaten Magelang, yaitu pelaku kegiatan, jenis kegiatan, pola kegiatan, sifat kegiatan, sifat organisasi.

b. Pemrograman performansi untuk menentukan skema kebutuhan ruang, persyaratan ruang, program ruang, dan lain-lain.

c. Analisis arsitektural merupakan tahap penggabungan dari hasil identifikasi program fungsional dan performansi. Proses ini dilakukan dengan analisis pengolahan tapak, pengolahan massa, tampilan bangunan, utilitas dan struktur bangunan yang

Langkah selanjutnya yaitu sintesis yang merupakan tahap penggabungan dari 
referensi dan hasil analisis fakta lapangan sehingga didapat kesimpulan untuk memperoleh konsep perancangan yang sesuai sehingga dapat ditransformasikan ke bentuk fisik yang diinginkan, yaitu Youth Center dengan pendekatan Arsitektur Regionalisme di Kabupaten Magelang.

\section{ANALISIS}

\subsection{Analisis Peruangan}

Analisis peruangan bertujuan untuk memperoleh jenis kebutuhan ruang dengan pertimbangan pengelompokan kegiatan dan pelaku kagiatan (lihat Tabel 1).

Tabel 1. Kebutuhan Ruang

\begin{tabular}{lll}
\hline Jenis & Pelaku & Peruangan \\
Kegiatan & & \\
\hline Penerimaa & Pengunjung & Parkir \\
Utama & Pengelola & Hall \\
& Pengunjung & R. Kesenian \\
& & Sport Hall \\
& & R. \\
& & Ketrampilan \\
\hline Penunjang & Pengunjung & R. Seminar \\
& Pengelola & Perpustaakaan \\
& & R. Pelatihan \\
& & Fisik \\
& & R. \\
& & Pertunjukan \\
& & R. Pameran \\
\hline Insidensial & Pengunjung & Sport Hall \\
& & R. \\
& & Pertunjukan \\
& & R. Pameran \\
\hline Pengelola & Pengelola & R. \\
& & Pengelolaan \\
& & R. \\
& & Operasional \\
& & R. Keamanan \\
& & R. Perawatan \\
\hline
\end{tabular}

\subsection{Analisis Pemilihan Lokasi}

Analisis pemilihan lokasi bertujuan untuk mendapatkan lokasi yang sesuai dan mendukung sebagai area didirikannya bangunan. Analisis pemilihan lokasi berdasarkan pada kriteria sebagai berikut:
1. Sesuai dengan tata guna lahan di Kabupaten Magelang

2. Dekat dengan fasilitas pendidikan dan olahraga

3. Mudah dicapai

4. Tapak yang terbuka dan mudah dilihat

Hasil analisis pemilihan lokasi :

Tapak terpilih yang akan dijadikan lokasi pembangunan Youth Center di Kabupaten Magelang, yaitu di Jalan Soekarno-Hatta. Tapak berbatasan langsung dengan $\mathrm{Jl}$. Soekarno-Hatta pada sisi timur, jalan lingkungan pada sisi selatan, lahan pertanian pada sisi barat dan utara (lihat Gambar 1).

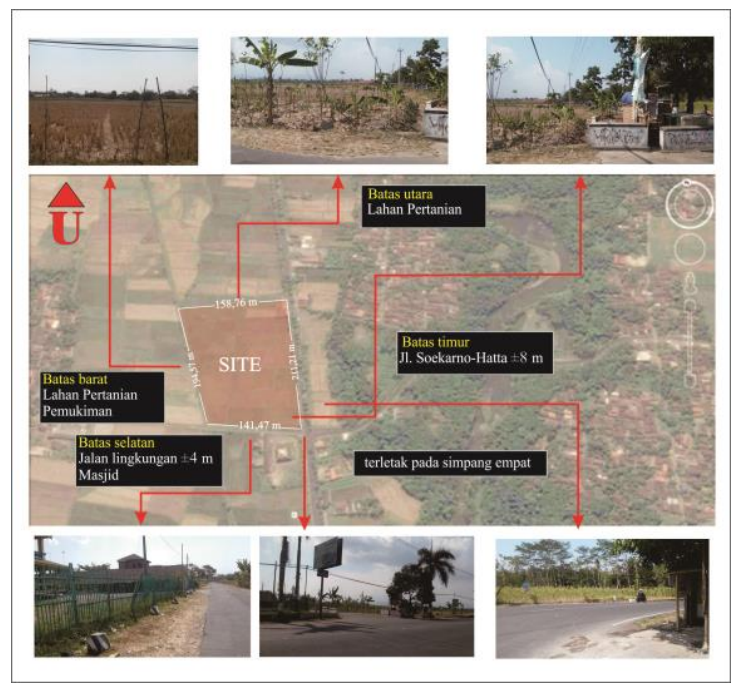

Gambar 1. Tapak Terpilih

Sumber: Dokumentasi Arifah, 2014

\subsection{Analisis Pencapaian}

Analisis pencapaian bertujuan untuk menentukan main entrance dan side entrance, dengan pertimbangan kondisi dan potensi jalan, sirkulasi yang jelas dan mudah dicapai serta keamanan dan kenyamanan sirkulasi.

Hasil analisis:

Main entrance (ME) bagi pengunjung diletakkan pada sisi timur tapak yang berbatasan langsung dengan Jl. SoekarnoHatta. Untuk akses ke luar tapak menggunakan akses yang berbeda yaitu pada sisi selatan yang berbatasan langsung dengan jalan lingkungan. Pemisahan 
antara jalur masuk dan ke luar sebagai upaya untuk mengurangi kepadatan jalan dan mencegah terjadinya kemacetan. Jalur ke luar masuk pengelola menggunakan side entrance (SE) yang terletak pada sisi bagian barat tapak di jalan lingkungan. Pemisahan antara ME dan SE dengan pertimbangan mencegah terjadinya crossing kegiatan sirkulasi antara pengunjung dan pengelola (lihat Gambar 2).

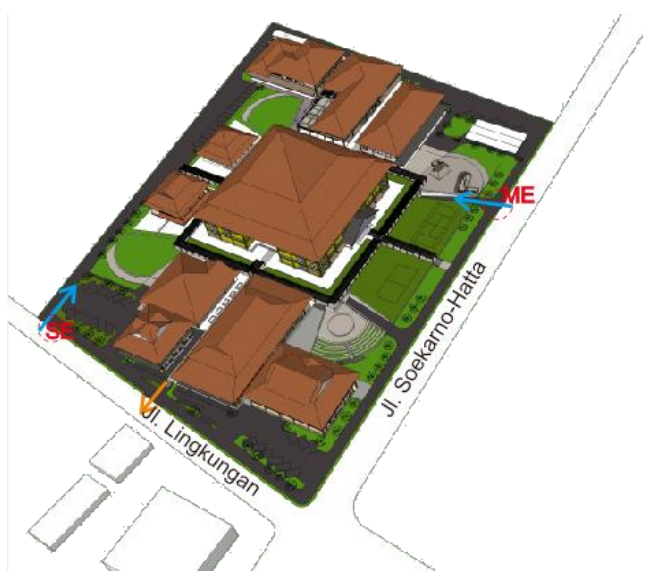

Gambar 2. Analisis Pencapaian

\subsection{Analisis Bentuk dan Tampilan Bangunan}

\subsubsection{Analisis penentuan konsep}

\section{Arsitektur Regionalisme}

Penentuan konsep Arsitektur Regionalisme digunakan untuk menentukan aspek-aspek yang terkait dalam konsep Arsitektur Regionalisme yang akan digunakan sebagai pertimbangan dalam proses perencanaan dan perancangan desain bangunan Youth Center di Kabupaten Magelang.

Arsitektur Regionalisme yang diangkat sebagai konsep perencanaan pada Youth Center di Kabupaten Magelang yaitu abstract regionalism, yang menggabungkan unsur-unsur kualitas abstrak bangunan dari Candi Borobudur yang terdapat di Kabupaten Magelang.

\subsubsection{Analisis bentuk bangunan}

Youth Center menggunakan pendekatan Arsitektur Regionalisme, sehingga bentuk massa bangunan menyesuaikan bangunan yang ada di sekitar tapak ataupun bangunan yang dapat mencerminkan budaya lokal Kabupaten Magelang. Bangunan yang diangkat pada perencanaan Youth Center di Kabupaten Magelang yaitu bangunan Candi Borobudur.

Bentuk dasar massa bangunan yang direncanakan diutamakan berbentuk persegi, dikarenakan mengikuti bentuk dasar denah pada Candi Borobudur. Selain itu dengan bentuk massa yang persegi, dapat lebih memudahkan penataan ruang dan sirkulasi bangunan serta mengoptimalkan fungsi ruang.

Tata massa bangunan pada Youth Center di Kabupaten Magelang terkait dengan konsep Arsitektur Regionalisme yaitu pada penerapan tata massa terpusat yang seimbang, seperti tata massa pada Candi Borobudur. Selain itu peletakan tata massa bangunan juga mempertimbangkan sifat ruang yaitu privat, semi publik, dan publik (lihat Gambar 3).

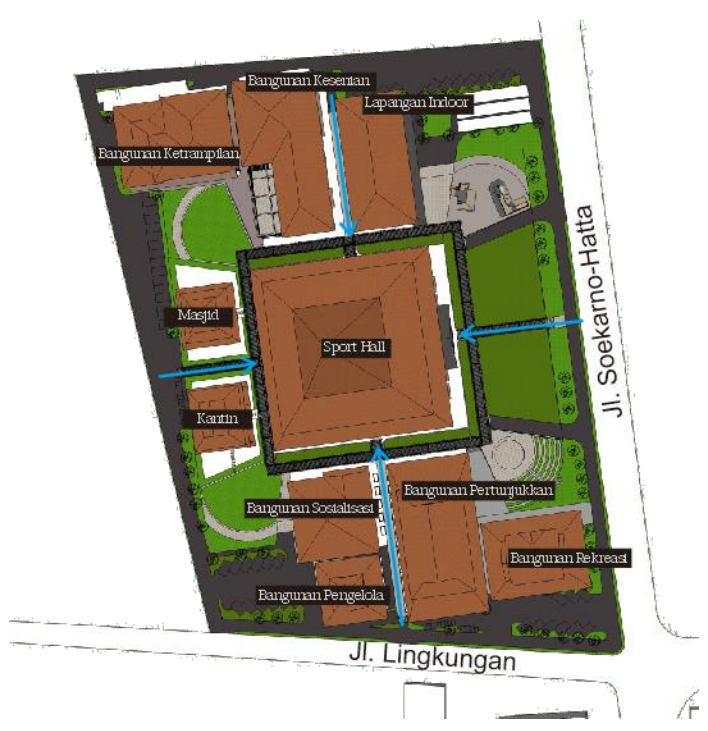

Gambar 3. Analisis Tata Massa Bangunan 


\subsubsection{Analisis tampilan bangunan}

Arsitektur Regionalisme pada tampilan bangunan Youth Center meliputi arsitektur yang terdapat pada Candi Borobudur dan bangunan sekitar serta terkait objek material.

Bentuk atap yang digunakan yaitu atap limasan, dengan material penutup berupa genteng tanah liat. Atap limasan dipilih karena menyesuaikan dengan bangunan sekitarnya, selain itu juga merupakan adaptasi dari bentuk stupa pada Candi Borobudur (lihat Gambar 4).

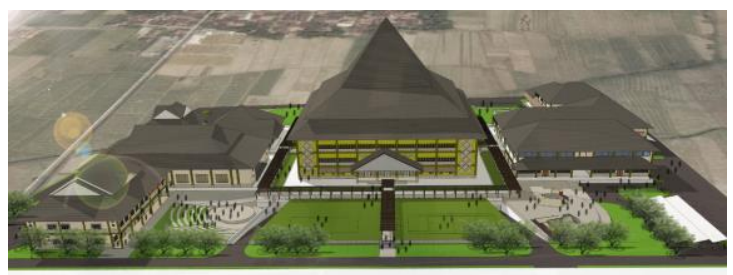

Gambar 4. Analisis Tampilan Bangunan

Ornamen yang terdapat pada bangunan Youth Center di Kabupaten Magelang yang direncanakan yaitu ornamen-ornamen yang terdapat pada ukiran-ukiran di dinding Candi Borobudur dan juga motif lubang yang terdapat pada stupa-stupa kecil Candi Borobudur. Material batu andesit diterapkan pada dinding dan juga panggung terbuka di halaman bangunan. Penggunaan warna pada bangunan Youth Center yaitu warna cerah yang menggambarkan semangat remaja. Hal tersebut diharapkan dapat memunculkan citra lokal Kabupaten Magelang dan identitas bangunan. (lihat Gambar 5).

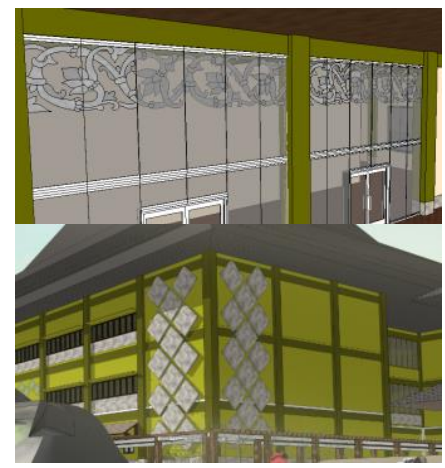

Gambar 5. Pengaplikasian Ornamen Candi Bobudur pada Bangunan

\subsubsection{Analisis Lansekap Kawasan}

Konsep lansekap kawasan pada Youth Center di Kabupaten Magelang tidak lepas dari konsep Arsitektur Regionalisme, yaitu konsep punden berundak yang diterapkan sesuai dengan kepentingan fungsi bangunan (lihat Gambar 6).

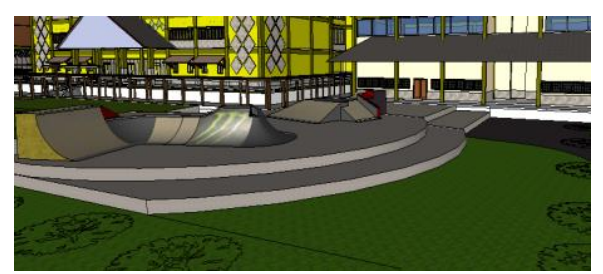

Gambar 6. Konsep Punden Berundak pada Bangunan

\section{KESIMPULAN (KONSEP DESAIN)}

Dari hasil analisa serta hasil korelasi dari beberapa data di atas, maka diperoleh hasil berupa desain Youth Center di Kabupaten Magelang sebagai berikut.
Lokasi
: Jl. Soekarno-Hatta
Luas Lahan
: 29.909,98 $\mathrm{m}^{2}$

Jumlah Lantai : 2-3 lantai

Daya Tampung : 757 orang

Pada bangunan Youth Center ini, konsep Arsitektur Regionalisme diterapkan dengan penggunaan bentuk yang mengambil dari bentuk dasar Candi Borobudur, tata pola massa terpusat dan seimbang seperti pada Candi Borobudur (lihat Gambar 3), penggunaan atap limasan sesuai dengan bangunan sekitar juga merupakan penggambaran dari bentuk stupa (lihat Gambar 4), menggunakan material lokal seperti batu andesit, mengaplikasikan oranamen-ornamen yang terdapat pada Candi Borobudur (lihat Gambar 5), serta pola tata lansekap punden berundak untuk lebih mencitrakan ciri khas lokal berupa Candi Borobudur (lihat Gambar 6). 


\section{REFERENSI}

Curtis, William, 1985. Regionalism in Architecture. Singapura. Concept Media.

Mappiare, Andi, 1982. Psikologi Remaja. Surabaya. Usaha Nasional

Dinas Pendidikan, Pemuda dan Olahraga Kabupaten Magelang 